\title{
EFFECT OF DIFFERENT DIETS ON GROWTH RATE OF THE RED SWAMP CRAYFISH, PROCAMBARUS CLARKII UNDER LABORATORYCONDITIONS
}

\author{
Madlen M. Habashy \\ National Institute of Oceanography and Fisheries, \\ Fish Research Station, El-Qanater El-khayriya, Egypt
}

Key words : Procambarus clarkii, growth rate, natural diets .

\section{ABSTRACT}

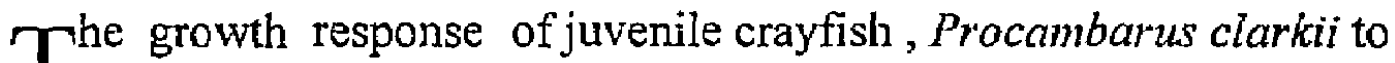
1 different fresh diets available from agriculture and freshwater ecosystem was examined under controlled conditions. These diets were fresh sweet potato tubers, Ipomaea batatcis, fiesh leaves of lettuce, Lactuca sativa, fresh fish meat from mosquitofish, Gambusia affinis, and all possible combinations of those ingredients for about two months. After 40 days, the results showed a significantly higher growth rate $(p<0.05)$ in both length and weight in crayfish fed with fresh fish meat The differences were not significant between other treatments, but those which included fish meat induced consistently higher growth rates than those based only on plant ingredients. These results suggest that a dietary supplement based on animal source might significantly improve the growth rate of the crayfish. However, it was not clear whether this was because of protein or lipid components and composition of mosquito fish meat.

\section{INTRODUCTION}

Procambarus clarkii (Girarad, 1852) is native to the south central United States and north eastern Mexico (Hobbs, 1972) and it was accidentally introduced to the Egyptian Nile water during the early 1980 (Ibrahim et al. 1995). It is a large prolific aggressive burrower species and well adapted to life in areas, with drastic seasonal fluctuations in water levels, where it survives in shallow, simple burrows (Huner \& Barr, 1991) Procambarus clarkil appears in some local markets as a cheap source of protein than other crustaceans such as shrimps which are expensive in Egypt . During the last few years . many countries in western Europe, paid much 
money for importing such crayfish both fresh and frozen (Holdich 1993; Laurent 1993; Ackelors and Lindquit 1994). This and other markets may be attractive enough to encourage its future well organized commercial exploitation in Egypt, where increasing population of the crayfish are already present and became abundant in the River Nile and its branches (Ibrahim et al. 1996).

The aim of this study was to assess the growth responses of juveniles crayfish to diets based on common feed stuffs which are locally abundant under laboratory conditions.

\section{MATERIALS AND METHODS}

The experiments were carried out at the invertebrate laboratory, Fish Research Station, El-Qanater El- Khayriya, National Institute of Oceanography and Fisheries, Cairo, Egypt.

\section{Experimental aquaria:}

Fourteen glass aquaria ( $40 \times 60 \times 30 \mathrm{~cm}$ ) were filled with 30 liters of dechlorinated tap water, that was continuously aerated by means of an electric compressor. Each aquarium was provided by some small plastic cylinders and stones that were put on the bottom to provide shelter for the crayfish .

\section{The crayfish:}

Juveniles of crayfish with a mean total length $1.5 \mathrm{~cm}$ and mean weight from 0.15 to $0.17 \mathrm{~g}$ were collected from ponds in Giza governorate. Crayfish were acclimatized to laboratory conditions for one week prior to the experiment. Crayfish were then transferred to the experimental glass aquaria and stocked at the density of 25 crayfish / aquarium. The experiments were carried out for about two months during June and July 2000 .

\section{Diets used:}

The experimental design consisted of seven treatments (diets) with two replicates. The diets were: (1) fresh sweet potato tubers, Ipomaea batatas, (2) fresh lettuce leaves, Lactuca sativa, (3) fresh 
EFFECT OF DIFFERENT DIETS ON GROWTH RATE OF THE RED 189 SWAMP CRAYFISH, PROCAMBARUS CLARKII UNDER LABORATORYCONDITIONS

meat of the mosquitofish Gambusia affinis, (4) a combination of 1 and 2, (5) a combination of 2 and 3, (6) a combination of 1 and 3, (7) a combination of 1,2 and 3 . The main nutritional values of sweet potato tubers and lettuce were obtained from published tables (Shaheen, 1996) and those of mosquitofish were evaluated in the laboratory as follow: dry samples of muscle were weighed and placed on filter papers.then they were placed in soxhlet, using petroleum ether $\left(60-80^{\circ} \mathrm{C}\right)$ as solvent, for a period $12-16$ hours, then put in an oven of $85^{\circ} \mathrm{C}$ for 2 hours for drying and weighed.

Fat content $=($ difference in weight $/$ weight of sample $) \times 100$

Protein content of muscle depends on determination of total nitrogen, then multiplying the nitrogen produced by 6.25 (Wrong,1923 and Alexander, 1956).

Nitrogen can be estimated by : a- wet oxidation of organic matter using micro-Kjeldhal .b- liberation of ammonia by sodium hydroxide then titration of ammonia by an acid.

The ash content was determined by overnight combustion at $550^{\circ} \mathrm{C}$ Food was supplied once a day (in the morning) and the remainder of food and detritus were siphoned while more than half the water was exchanged every two days .

\section{Water analysis}

Water analysis was carried out weekly to determine dissolved oxygen, pH value, phosphate and nitrites according to Arnold et al. (1980) while the Water temperature was recorded daily.

Every ten days and when the experiments finished ( 60 days) all the individuals were collected, counted, measured (total length from rostrum to telson ) to the nearest centimeter and weighed to the nearest $0.01 \mathrm{~g}$ on an electronic balance.

The data obtained were treated by analysis of variance, using $F$ test and Duncan's multiple range at 0.05 significance level, according to Steel and Torrie (1980).

\section{RESULTS}

Water quality of the experimental aquaria is shown in Table (1), average water temperature ranged from $27.1^{\circ} \mathrm{C}$ to $27.5^{\circ} \mathrm{C}, \mathrm{pH}$ 
values from 7 to 7.5 and dissolved oxygen from 5.9 to $6.8 \mathrm{mg} / 1$ for different treatments.

The nutritional composition of the feeds used in the experiment is shown in Table (2). The mosquitofish meat seems to be the best balanced diet because of its high protein content and moderate amounts of lipids and minerals. Sweet potato tubers has a reasonable protein content as a vegetable but, has a high amount of fiber. Isettuce was the worst dict for crayfish, since its protein and lipid contents are poor.

The initial length and weight were not significantly different between treatments. The results obtained throughout the experiment are shown in Table (3). Treatment 3, (with fresh mosquitofish meat), started to induce a significantly higher wieght $(p<0.05)$, after 30 days, but in size (length) after 40 days. This variation was maintained until the end of the experiment ( 60 days ), the difference between other treatments were not statistically significant $(p>0.05)$, but the treatments including fish meat gave consistently higher results than those based only on vegetable product (Fig. 1 ).

The average length and weight at the end of the experiment were respectively higher than $3.0 \mathrm{~cm}$ and $1.0 \mathrm{~g}$ only in the treatments including fish meat alone or in combination with other feed stuffs. No significant difference was observed between results after feeding with sweet potato tubers and lettuce, either used alone or in combination with fish meat.

At the end of the experiment, the highest survival rate $(77 \%)$ was obtained in treatment 5 , consisting of a combination of fish meat and lettuce, but feeding with fish meat alone (treatment 3 ) and with a combination of sweet potato tubers and lettuce (treatment 7 ) gave a close second best both with approximately $71 \%$ survival. The lowest survival rate( $45 \%$ ) was reported after feeding with lettuce alone (treatment 2) ), where feeding with fish meat plus sweet potato tubers (treatment 6), or feeding with sweet potato tubers in combination with lettuce ( treatment 4 ), both had a survival rate of $65 \%$, while sweet potato tubers alone (treatment 1) gave approximately $58 \%$ survival. 


\section{DISCUSSION}

As a matter of fact, fresh vegetables are not frequently used as crayfish feeds, and references on their nutrition relevance for this species are very scarce. The present results obtained in the treatments using just fresh vegetable feed stuffs suggest that they represent a very poor dietary supplement, at least in such a fresh condition. Huner and Meyers ( 1979 ) found that proteins of animal origin might have a significant positive effect on the growth of juvenile red swamp crayfish. They concluded that a concentration of $15 \%$ of gross animal protein in the diet was the lowest acceptable value for feeding red swamp crayfish. They did not find any significant difference in the growth rate within the range of $15-44 \%$ of gross animal protein concentration, and suggested, that gross animal protein concentration within the range of $15-62 \%$ would not result in any difference based on their own and other data.

In the present experiments, where a diet with $67.1 \%$ protein of animal origin was used in treatment 3 and protein concentration within the range of $15-65 \%$ were accessible to the crayfish in treatments 5, 6, and 7, significant differences in growth response were found between the diet with the highest protein concentration and the others. In addition, the differences between diets with and without animal protein, excluding treatment 3 , were not significant (Table 2), although a clear trend for higher growth rates was observed in treatments with animal component, compared to those without such component. Although such results suggest a different conclusion from that obtained by Huner and Meyers (1979), Brown et al. (1986) and Reigh et al. (1990), it must be stressed that those authors did not use fresh animal protein and that the present experimental conditions did not include any decomposing feed stuffs, meaning that the microbial populations occurring during the decomposition processes were not contributing significantly as an extra, uncontrolled source of protein to the diets .

The nutritional requirements of crustaceans and in particular of red swamp crayfish are not yet completely studied (Reigh et al. 1990 ; Van-Wormhoudt and Bellon-Humbert, 1994). The digestibility of proteins in the diet of crustaceans depends mainly on the proportion of amino acids and especially, of limiting amino acids. However, the proteolitic characteristics are variable from one species 
to another and the optimum protein composition for red swamp crayfish was not yet classified (Oliveira \& Fabiao, 1998 ).

Lipid also plays an important role in the nutrition of aquatic animals, especially in decapod crustaceans, which are incapable of producing linoleic and linolenic acids ( D'Abramo \& Robinson, 1989; Van-Worhoudt \& bellon-Humbert, 1994). This suggests that, in future experiments, the nutritional characteristics of mosquitofish meat must be studied and described in greater detail, allowing a better understanding of its potential as a dietary component for crustaceans, especially, for red swamp crayfish .

The main conclusion of this experiment is that a feeding supplement of mosquitofish meat, with a high concentration of gross animal protein and lipids, may contribute to faster growth of juvenile red swamp crayfish .

\section{REFERENCES}

Ackefors IH. and Lindqvist O. V. (1994). Cultivation of freshwater crayfish in Europe. In : "Freshwater crayfish". Aquaculture in North America, Europe, and Astralia:Families Astscidae, Cambaridae, and Parastacidae (ed.by J. V. Huner ), pp. 157216. Food Products Press Binghamton.

Arnold, E. G. ; Joseph, J. C. and David, J. (1980). "Standard Methods for the Examination of water and Wastewater".15th ed.American Public Health Association, Washington.

Brown, P. B. ; Williams, C. D ; Robinson, E. H. ; Akiyama, D. M. and Lawrence, A. L. ( 1986 ). Evaluation of methods for determining in vivo digestion coefficients for adult red swamp crayfish Procambarus clarkii. J. of the World Aquacult. Soc., 17: $19-24$.

D'Abramo, L. R. and Robinson, E. H. (1989). Nutritional of crayfish. Reviews in Aquatic Sciences, $1: 711-728$. 
Hobbs, H. H. Jr ( 1972 ). Biota of freshwater Ecosystems, Identification Manual $9:$ crayfishes (Astracidae) of North and Middle America. Environmental protection Agency reprinted in 1976.

Holdich, D. M. ( 1993 ). A review of astaciculture: freshwater crayfish farming. Aquatic. Living Resources, 6: 307 -317.

Huner, J. V. and Bart, J. E. ( 1991 ). Red swamp crayfish: Biology and exploitation. Louisiana Sea Grant College Program, Louisiana State Univ, Baton Rouge, Louisiana U. S. A. ( 3 $r d$. ed)

Huner J. V. and Meyers S. P. (1979). Dietary protcin requirement of the red crayfish, Procambarus clarkii (Girard) (Decapoda, Cambaridae) grown in a closed system. Proceeding of the World Mari culture society., 10:751 - 760 .

Ibrahim, A. M.; Khalil, M. T. and Mubarak, F. M. ( 1995 ). On the feeding behavior of the exotic crayfish Procambarus clarkii in Egypt and its prospects in the biocontrol of local vector snails J. Union Arab. Zool., 4 (A) : 321 - 340.

Ibrahim, A. M.; Khalil, M. T. and Mubarak, F. M. ( 1996 ). Ecological studies on the Exotic crayfishes Procambarus clarkii ( Girard, 1852) and P. zonangulus Hobbs \& Hobbs, 1990, in the River Nile Egypt. Ger. Soc. Zool., 20 (D): $167-185$.

Laurent, P. J. ( 1993 ). Les importations d,ecrevisses en France en (1992). L'Astaciculteur de France, 35: 11 - 17.

Oliveira, J. and Fabiao, A. ( 1998 ). Growth responses of juvenile red swamp crayfish, Procambarus clarkii Girard, to several diets under controlled conditions Aquacult. Research, 29: $123-129$. 
Reigh, R. C.; Braden, S. L. and Craig R. J. ( 1990 ). Apparent digestibility coefficients for common feedstuffs in formulated diets for red swamp crayfish. Procambarus clarkii Aquacult., 84: 321 - 334. Shaheen, F.M. (1996). Food composition tables for Egypt. Nutrition Institute. A. R. E., $115 \mathrm{pp}$.

Steel, R. G. D. and Torrie, J. H. ( 1980 ). Principal procedures of statistics. A Biometrical Approach. Mc Graw - Hil International Editions. Singapore.

Van-Wormhoudt, A. and Bellon - Humbert C. (1994). Crustacean farming : the biological basis. In : Aquaculture. Biology and Ecology of Cultured Species", ( ed. By G. Barnabe). pp. 174 - 223. Ellis Horwood series in Aquacult. and Fisheries Support. Ellis Horwood. London. 
Table (1): water quality of the experimental aquaria throughout the experimental period (average values).

\begin{tabular}{|l|l|l|l|l|l|l|l|l|}
\hline \multirow{2}{*}{ Item } & \multicolumn{5}{|c|}{ Different Treatments } & \multicolumn{2}{c|}{} \\
\cline { 2 - 10 } & 1 & 2 & 3 & 4 & 5 & 6 & 7 \\
\hline Water Temperature $\mathrm{C}$ & 27.5 & 27.1 & 27.3 & 27.5 & 27.5 & 27.3 & 27.5 \\
\hline pH values & 7.5 & 7.2 & 7 & 7.1 & 7.1 & 7.5 & 7.1 \\
\hline Dissolved Oxygen (mg/l) & 6.5 & 5.9 & 6.3 & 6.1 & 6.5 & 6.2 & 6.8 \\
\hline
\end{tabular}

Table (2) Main nutritional composition of the feed stuffs used in the experiment

\begin{tabular}{|l|l|l|l|}
\hline Composition & Sweet potato & Lettuce & Mosquito fish meat \\
\hline Protein & 1.8 & 1.1 & 67.1 \\
Lipids & 0.3 & 0.2 & 14.3 \\
Carbohydrate & 23.1 & 2.5 & 3.9 \\
Fiber & 1.2 & 0.7 & - \\
Ashes & 1.3 & 0.8 & 16.5 \\
\hline
\end{tabular}

Composition of Foods / 100 Grams . 
Table (3) : Mean initial values for individual body length and weight in each treatment and throughout the experimental period.

\begin{tabular}{|l|l|l|l|l|l|l|l|}
\hline \multirow{2}{*}{ Treatment } & \multirow{2}{*}{$\begin{array}{l}\text { Initial } \\
\text { Size }\end{array}$} & \multicolumn{9}{|c|}{\begin{tabular}{l} 
Growth \\
\cline { 3 - 8 }
\end{tabular}} & $\begin{array}{l}\text { After } \\
\text { 10 days }\end{array}$ & $\begin{array}{l}\text { After } \\
20 \text { days }\end{array}$ & $\begin{array}{l}\text { After } \\
30 \text { days }\end{array}$ & $\begin{array}{l}\text { After } \\
40 \text { days }\end{array}$ & $\begin{array}{l}\text { After } \\
50 \text { days }\end{array}$ & $\begin{array}{l}\text { After } \\
60 \text { days }\end{array}$ \\
\hline Length & & & & & & & \\
(cm) & 1.5 & 1.8 & 1.8 & $2.1^{\mathrm{b}}$ & $2.1^{\mathrm{b}}$ & $2.3^{\mathrm{b}}$ & $2.5^{\mathrm{b}}$ \\
1 & 1.5 & 1.6 & 1.7 & $1.7^{\mathrm{b}}$ & $1.9^{\mathrm{b}}$ & $2^{\mathrm{b}}$ & $2.3^{\mathrm{b}}$ \\
2 & 1.5 & 2.5 & 3.3 & $4.0^{\mathrm{b}}$ & $4.5^{\mathrm{b}}$ & $5.6^{\mathrm{b}}$ & $6.2^{\mathrm{b}}$ \\
3 & 1.5 & 2 & 1.9 & $1.8^{\mathrm{b}}$ & $2.0^{\mathrm{b}}$ & $2.2^{\mathrm{b}}$ & $2.5^{\mathrm{b}}$ \\
4 & 1.5 & 2.1 & 2.2 & $2.3^{\mathrm{b}}$ & $2.7^{\mathrm{b}}$ & $3.4^{\mathrm{b}}$ & $3.5^{\mathrm{b}}$ \\
5 & 1.5 & 1.8 & 2.3 & $2.5^{\mathrm{b}}$ & $3.0^{\mathrm{b}}$ & $3.5^{\mathrm{b}}$ & $3.6^{\mathrm{b}}$ \\
6 & 1.5 & 1.9 & 2.3 & $2.4^{\mathrm{b}}$ & $2.8^{\mathrm{b}}$ & $3.4^{\mathrm{b}}$ & $3.7^{\mathrm{b}}$ \\
7 & & & & & & & \\
Weight (g) & & & & & & & \\
1 & 0.16 & 0.22 & 0.26 & $0.27^{\mathrm{b}}$ & $0.46^{\mathrm{b}}$ & $0.48^{\mathrm{b}}$ & $0.55^{\mathrm{b}}$ \\
2 & 0.16 & 0.19 & 0.21 & $0.20^{\mathrm{b}}$ & $0.24^{\mathrm{b}}$ & $0.39^{\mathrm{b}}$ & $0.54^{\mathrm{b}}$ \\
3 & 0.16 & 0.56 & 1.30 & $2.08^{\mathrm{a}}$ & $3.43^{\mathrm{a}}$ & $6.6^{\mathrm{b}}$ & $8.02^{\mathrm{a}}$ \\
4 & 0.15 & 0.21 & 0.25 & $0.25^{\mathrm{b}}$ & $0.29^{\mathrm{b}}$ & $0.52^{\mathrm{b}}$ & $0.77^{\mathrm{b}}$ \\
5 & 0.16 & 0.33 & 0.49 & $0.69^{\mathrm{b}}$ & $1.02^{\mathrm{b}}$ & $1.51^{\mathrm{b}}$ & $1.99^{\mathrm{b}}$ \\
6 & 0.16 & 0.30 & 0.35 & $0.38^{\mathrm{b}}$ & $0.64^{\mathrm{b}}$ & $1.29^{\mathrm{b}}$ & $1.85^{\mathrm{b}}$ \\
7 & 0.17 & 0.26 & 0.53 & $0.59^{\mathrm{b}}$ & $0.87^{\mathrm{b}}$ & $1.27^{\mathrm{b}}$ & $1.77^{\mathrm{b}}$ \\
\hline
\end{tabular}

Values followed by different superscript characters in the same column were significantly different $(\mathrm{P}<0.05)$.
(1) Fresh sweet potato
(2) Fresh lettuce leaves
(3) Fresh Mosquitofish meat
(4) a combination of 1 and 2
(5) a Combination of 2 and 3
(6) a combination of 1 and 3
(7) a combination of 1,2 and 3 


\section{EFFECT OF DIFFERENT DIETS ON GROWTH RATE OF THE RED 197 SWAMP CRAYFISH, PROCAMBARUS CLARKII UNDER LABORATORYCONDITIONS}
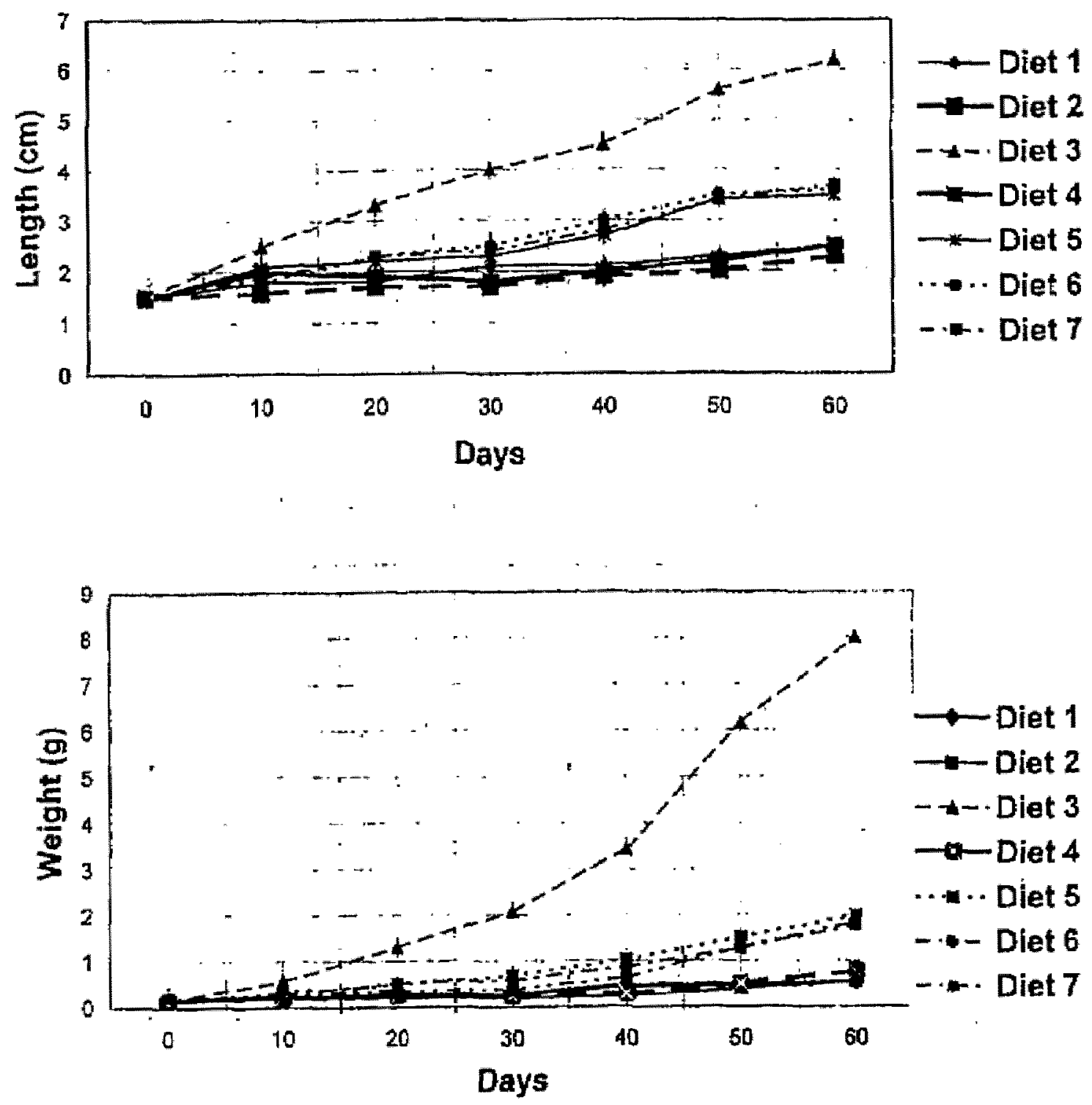

Diet 1, Sweet Potato

Dlet 2, Lottuce

Diet 3, Fish meat

Diet 4, Potato+Lettuce
Diet 5, Lettuce+fish meat

Diet 6, Potato+Fish meat

Diat 7, Potato+Lettuce+Fish moat

Fig (1) Increase in length (top) and weight (bottom ), during the' experimental period of red swamp craytlsh fed the treatment diets. 